\title{
Facile conversion of tetracycline antibiotics to 4,11 a-bridged derivatives via oxidative mannich cyclization
}

\author{
Jianxin $\mathrm{Gu}^{1}$, Ping $\mathrm{Cai}^{1}$, Yumin Gong ${ }^{2}$, Mark E Ruppen ${ }^{1}$ and Thomas Storz ${ }^{3}$ \\ Treatment of a variety of tetracyclines (tigecycline, minocycline, tetracycline and doxycycline) with $\mathrm{Ag}_{2} \mathrm{CO}_{3} / \mathrm{EDTA}$ or $\mathrm{Hg}(\mathrm{OAc})_{2}$ \\ cleanly gave the 4,11a-bridged derivatives in high yields. The reactions proceeded through a novel, intramolecular Mannich \\ cyclization of an iminium species generated by oxidation of the tertiary dimethylamino group at $\mathrm{C}(4) \mathrm{by} \mathrm{Ag}(\mathrm{I})$ or $\mathrm{Hg}(\mathrm{II})$. \\ Tetracyclines without 5-OH-substitution (tigecycline, tetracycline and minocycline) gave the 4-OH-substituted, 4,11a-bridged \\ compound, whereas doxycycline gave the 4-dimethylamino-substituted, 4,11a-bridged product. In the case of tetracycline, the \\ 4,11a-bridged compound can equilibrate further to a 4,6-bridged hemiketal. Some of the bridged compounds underwent a novel \\ decarboxylation-rearrangement sequence under acidic conditions to give tricyclic, open chain 1,4-quinoid compounds.
}

The Journal of Antibiotics (2010) 63, 693-698; doi:10.1038/ja.2010.119; published online 27 October 2010

\section{INTRODUCTION}

Tetracycline (Tc) antibiotics have been widely used in human and veterinary medicine for over five decades. The $\mathrm{N}$-tert-butylglycylcycline derivative tigecycline (Tygacil) is the most recent compound designed to combat bacterial infections resistant to previous agents. ${ }^{1,2}$ Synthetic methods to increase the diversity space of tigecycline and its derivatives are still quite limited (see, for instance refs 3 and 4). 3,4 During a study on glucuronide derivatives of tigecycline it was discovered that tigecycline, when treated with certain oxidants in polar aprotic solvents, undergoes a clean transformation to a 4,11abridged compound that contains a new norbornyl ring within the molecule. This product resembles the structure of several photoproducts ('lumitetracyclines') of members of the tetracycline family formed upon exposure to long wavelength UV light. ${ }^{5,6}$ We undertook a detailed investigation of the scope and mechanism of this reaction in order to understand its value as a potentially general derivatization method for other members of the tetracycline family.

\section{RESULTS AND DISCUSSION}

Tigecycline and minocycline

In the course of a detailed study on various oxidants (data not shown) we found a combination of $\mathrm{Ag}_{2} \mathrm{CO}_{3} /$ EDTA to be ideal for the conversion of tetracyclines to analogous bridged compounds. As depicted in Scheme 1, the conversion of tigecycline 1 to 4,11a-bridged 4 proceeded smoothly to completion within $18 \mathrm{~h}$ at room temperature in dimethyl sulfoxide (DMSO) in the presence of EDTA and $4 \AA$ molecular sieves, through an iminium cation/Mannich cyclization pathway, returning 4 as the only product as determined by ${ }^{1} \mathrm{H}$,
${ }^{13} \mathrm{C}$ NMR. Compound 4 was rapidly hydrolyzed and appeared in the form of another 4,11a-bridged compound 7 during reversed-phase HPLC analysis (96\% assay yield). Compound 7 can be isolated in $83 \%$ yield by preparative HPLC after adding the reaction mixture to a saturated EDTA disodium solution. The conversion of 4 to 7 most likely proceeds through the iminium intermediate $\mathbf{3}$, and the 1,4-quinone (Scheme 1).

The presence of EDTA was found to be critical for the success of this reaction. It may function (1) as competitive chelating agent to reduce or minimize the strong irreversible binding of tigecycline to silver ions. It is known that tetracyclines can form strong metal complexes $[\mathrm{MTc}]^{+}$with a variety of metal ions through the oxygen atoms of the tricarbonylmethane chromophore, ${ }^{7,8}$ and indeed, a large amount of yellow powder was quickly observed when tigecycline $\mathbf{1}$ was mixed with $\mathrm{Ag}_{2} \mathrm{CO}_{3}$ in $\mathrm{MeCN}$; (2) as an activator for the $\mathrm{Ag}(+)$ and/or a shuttle for silver ions to be delivered into solution, as it is known that aminopolycarboxylate chelating agents, such as EDTA, will significantly increase the solubility of metals through ligand-promoted dissolution. ${ }^{9,10}$ The fact that a less polar solvent, such as acetonitrile, gave no reaction, suggests that the complexation of $\mathrm{Ag}(+)$ and EDTA and/or solubility of the $\mathrm{Ag}(+)$ /EDTA complex are important factors for the success of this conversion. Without EDTA, under the same conditions (DMSO, room temperature), no trace of $\mathbf{4}$ or 7 was detected by HPLC-MS. However, precomplexation between EDTA/ $\mathrm{Ag}_{2} \mathrm{CO}_{3}$ before the addition of 1 was found unnecessary, indicating that the metal complex formation constant of the EDTA/silver complex appears to be far higher than the metal complex formation constant of the tetracycline-silver complex $[\mathrm{MTc}]^{+}$, at least in DMSO

${ }^{1}$ Vaccine Research \& Early Development, Pfizer Biotherapeutics, Pearl River, NY, USA; ${ }^{2}$ Analytical Research \& Development, Pfizer PharmaTherapeutics, Pearl River, NY, USA and ${ }^{3}$ Chemical Research \& Development, Pfizer PharmaTherapeutics, Groton, CT, USA

Correspondence: Dr T Storz, Chemical Research and Development, Pfizer PharmaTherapeutics, Eastern Point Road, Groton, CT 06340, USA.

E-mail: thomas.storz@pfizer.com

Received 11 June 2010; revised 16 August 2010; accepted 29 September 2010; published online 27 October 2010 


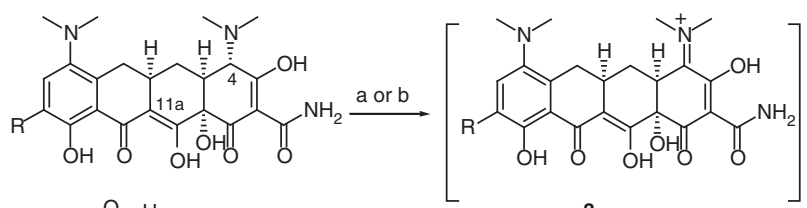<smiles>[R]NC(=O)NC(C)(C)C</smiles><smiles>C=CC</smiles><smiles>Cc1cc(N(C)C)c2c(c1O)C(=O)C1=C(O)[C@]3(C)C(=O)C(C(N)=O)=C(O)C(=O)[C@@H]3C[C@H]1C2</smiles>

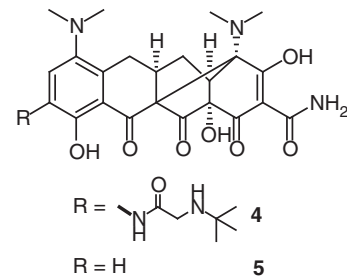

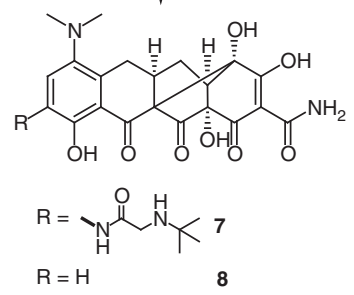

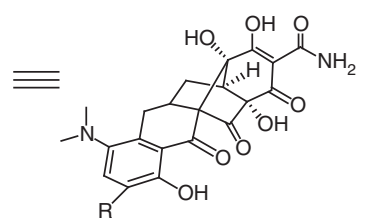

Scheme 1 Conversion of tigecycline and minocycline to 4,11a-bridged derivatives by $\mathrm{Ag}_{2} \mathrm{CO}_{3} / \mathrm{EDTA}$ or $\mathrm{Hg}(\mathrm{OAc})_{2}$. ${ }^{\mathrm{a}} \mathrm{Conditions}$ for tigecycline: $\mathrm{Ag} 2 \mathrm{CO}_{3}(2$ equiv.), EDTA (1.2 equiv.), DMSO, rt, $1 \mathrm{~h}$, then tigecycline (1 equiv.), $4 \AA \mathrm{MS}, \mathrm{rt}, 18 \mathrm{~h}$; conditions for minocycline: $\mathrm{Ag}_{2} \mathrm{CO}_{3}$ (2.2 equiv.), EDTA (1.2 equiv.), DMF, $50{ }^{\circ} \mathrm{C}$, $1 \mathrm{~h}$, then minocycline ( 1 equiv.), $4 \AA \mathrm{MS}, 35^{\circ} \mathrm{C}, 40 \mathrm{~h}$. ${ }^{\mathrm{b}}$ Conditions: tigecycline or minocycline (1 equiv.), $\mathrm{Hg}(\mathrm{OAc})_{2}(1.2 \mathrm{equiv}$.), $4 \AA \mathrm{MS}, \mathrm{DMF}, \mathrm{rt}, 1-2 \mathrm{~h}$.

or $\mathrm{N}, \mathrm{N}$-dimethylformamide (DMF) as a solvent (for better comparability of rates/results, all $\mathrm{Ag}^{+} / \mathrm{EDTA}$ experiments were carried out in the same manner (with precomplexation); the indifference of the tigecycline oxidation to $\mathrm{Ag}^{+}$/EDTA precomplexation was discovered later).

Other known metal chelating agents, such as ethylenediamine $N, N^{\prime}$ diacetic acid, polyamines, such as HMTTA $(1,1,4,7,10,10$-hexamethyltriethylene-tetramine), and TMEDA $\left(N, N, N^{\prime}, N^{\prime}\right.$-tetramethylethylenediamine), led to the decomposition of $\mathbf{1}$, and none of the desired 4 or 7 was detected.

Minocycline 2 underwent the same conversion by the $\mathrm{Ag}_{2} \mathrm{CO}_{3} /$ EDTA system (Scheme 1). However, it required longer reaction times and higher temperatures. DMF was found to be a superior solvent over DMSO in this case. Similarly, $\mathbf{5}$ also proved to be hydrolytically labile and converted to compound $\mathbf{8}$ during reverse-phase HPLC analysis (92\% assay yield). After workup and isolation by preparative HPLC, 8 was isolated in $66 \%$ yield. Unlike tigecycline in DMSO, the precomplexation of $\mathrm{Ag}_{2} \mathrm{CO}_{3}$ with EDTA in DMF was found necessary for an efficient conversion of $\mathbf{2}$ to $\mathbf{5}$.

Other silver reagents proved less effective. For example, the combination of $\mathrm{Ag}_{2} \mathrm{O}$ and EDTA gave $85 \%$ assay yield of 7 from tigecycline, while yielding a complex mixture with only $15 \%$ of $\mathbf{8}$ from minocycline. Similarly, only $57 \%$ assay yield of 7 (from tigecycline) was observed when $\mathrm{AgClO}_{4} /$ EDTA was employed (unlike $\mathrm{AgCO}_{3}$, neither $\mathrm{AgO}$ nor $\mathrm{AgClO}_{4}$ led to the pure formation of $4 / 5$ (as judged by NMR) and a lower yield of $\mathbf{7 / 8}$ was observed after hydrolysis. $\mathrm{AgNO}_{3}$ was not tested).

\section{Tetracycline}

A slower conversion yielding a complex mixture was seen when similar conditions were applied to tetracycline (Scheme 2). Initially, using the same HPLC sample preparation procedure as for $4 / 5$, two peaks corresponding to 4,11a-bridged tetracycline 11 and 4,1la-bridged tetracycloxide $\mathbf{1 3}$ (total $75 \%$ assay yield, $\mathbf{1 1 / 1 3}$ ratio: $77.3 / 22.7$ ) were observed. Apparently, the iminium intermediate $\mathbf{1 0}$ is more stable towards hydrolysis in this case. Further studies showed that the hydrolysis of $10 / 11$ in the saturated EDTA-2Na ( $\mathrm{pH} 5.5)$ solution was indeed slower, when compared with the hydrolysis of $3 / 4 / 5$, which rapidly convert to $7 / 8$ upon contact with water. For example, about half of 11 remained after $1 \mathrm{~h}$ at $0-5{ }^{\circ} \mathrm{C}$ in aqueous EDTA solution. This improved aqueous stability might be attributed to intramolecular stabilization of the 4-iminium cation by the hydroxyl group at $\mathrm{C}(6)$. Examination of a Dreiding model of intermediate 10 suggested that such an interaction will force the A, B ring into a twist conformation, which facilitates Mannich cyclization to the bridged compound $\mathbf{1 1 .}$

A closer examination of the hydrolytic process revealed that, although the initial product was 4,11a-bridged 13, the latter can further equilibrate to the 4,6-hemiketal 14 most likely through the 1,4-quinoid compound 12 via a retro-aldol reaction. From examining the molecular model the less strained 4,6-hemiketal 14 would be expected to be thermodynamically favored over the 4,11a-bridged 13 .

Upon aging 13 in methanol for 2 days, the 4,6-hemiketal 14 steadily increased until the ratio of $14 / 13$ reached $\sim 55: 45$. The same equilibrium ratio was also observed during NMR analysis in $\mathrm{D}_{6}$-DMSO.

\section{Doxycycline}

As discussed above, the increased stability of the 4,11a-bridged tetracycline derivative $\mathbf{1 1}$ towards hydrolysis can be attributed to the presence of a hydroxy group at $\mathrm{C}(6)$ in the iminium intermediate $\mathbf{1 0}$. As for doxycycline, we envisaged that a neighboring hydroxyl group at $\mathrm{C}(5)$ should further increase the stability of the corresponding 4,11abridged derivative. This prediction was confirmed by synthesis of the 4,11a-bridged doxycycline 19. Doxycycline was first treated with $\mathrm{Ag}_{2} \mathrm{CO}_{3} /$ EDTA in DMF ( $96 \%$ assay yield by HPLC), followed by aqueous hydrolysis under the same conditions that led to $\mathbf{7 / 8}$. Remarkably, 19 was found to be completely stable toward hydrolysis and was recovered as the only product in good yield (80\%); no trace of 
hydrolysis product 21 was detected, confirming the exceptional stabilization effect of the neighboring C(5)-hydroxyl group.

\section{Mechanism/stability}

The tertiary 4-iminium intermediate (3 in Scheme 1, 10 in Scheme 2 and 18 in Scheme 3 ) was previously proposed by Esse et al. ${ }^{11}$ during
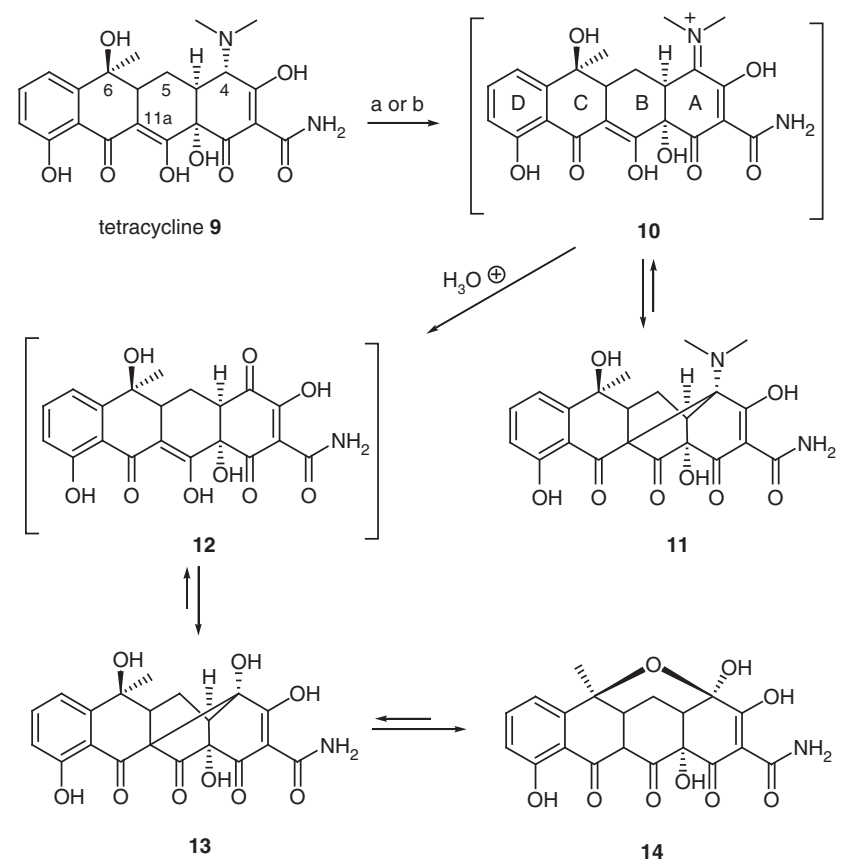

Scheme 2 Reaction of tetracycline with $\mathrm{Ag}_{2} \mathrm{CO}_{3} /$ EDTA or $\mathrm{Hg}(\mathrm{OAc})_{2}$. aConditions: $\mathrm{Ag}_{2} \mathrm{CO}_{3}$ (2.2 equiv.), EDTA (1.2 equiv.), DMF, $50^{\circ} \mathrm{C}, 1 \mathrm{~h}$, then tetracycline ( 1 equiv.), $4 \AA \mathrm{MS}, 37^{\circ} \mathrm{C}, 48 \mathrm{~h}$. ${ }^{\mathrm{b} C}$ Conditions: tetracycline (1 equiv.), $\mathrm{Hg}(\mathrm{OAc})_{2}$ (1.2 equiv.), $4 \AA \mathrm{MS}, \mathrm{DMF}, \mathrm{rt}, 2-3 \mathrm{~h}$.
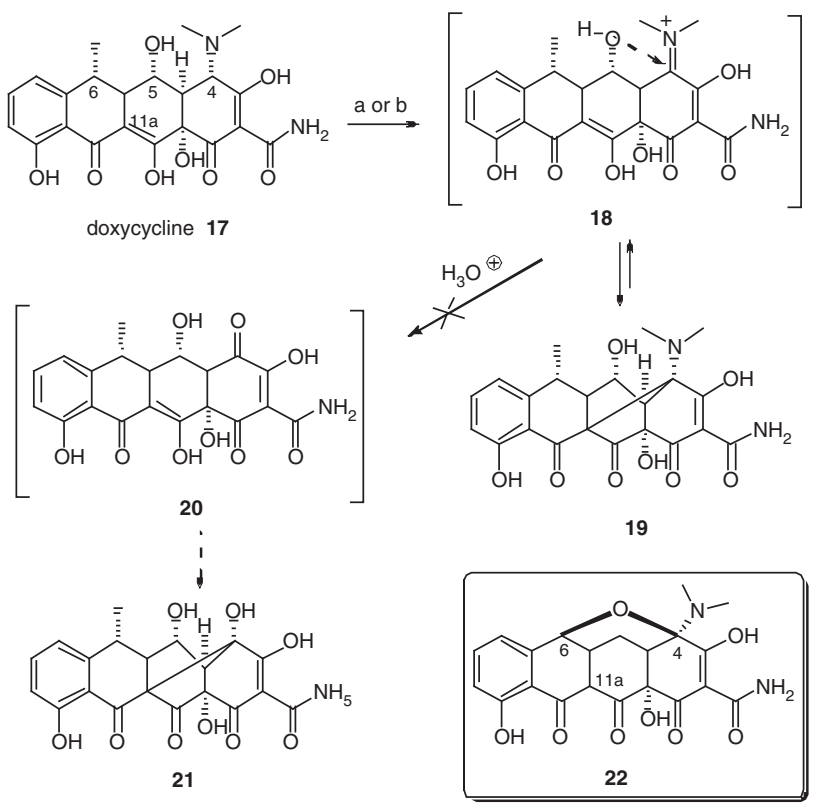

Scheme 3 Conversion of doxycycline to 4,11a-bridged derivatives by $\mathrm{Ag}_{2} \mathrm{CO}_{3} /$

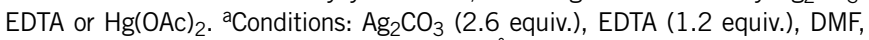
$50{ }^{\circ} \mathrm{C}, 1 \mathrm{~h}$, then doxycycline ( 1 equiv.), $4 \AA \mathrm{MS}, 37^{\circ} \mathrm{C}, 40 \mathrm{~h}$. ${ }^{\mathrm{b}}$ Conditions: doxycycline (1 equiv.), $\mathrm{Hg}(\mathrm{OAc})_{2}$ (1.2 equiv.), $4 \AA \mathrm{MS}, \mathrm{DMF}, \mathrm{rt}, 6 \mathrm{~h}$. their investigation on the reaction of 6-demethyltetracycline with mercuric acetate, which, as the authors believed, led to the formation of 4,6-bridged 22 (Scheme 3). Our reexamination found that the reaction initially afforded a mixture of at least of two products as observed by ${ }^{13} \mathrm{C}$ NMR after $1 \mathrm{~h}$ with 1.2 equivalents of $\mathrm{Hg}(\mathrm{OAc})_{2}$. The complexity of the ${ }^{13} \mathrm{C}$ NMR spectrum gradually simplified over a $10 \mathrm{~h}$ period, and the pentacyclic tetrahydropyrane 22 emerged as the dominant product. The action of $\mathrm{Hg}(\mathrm{OAc})_{2}$ on 6-demethyltetracycline appeared to furnish the 4,11a-bridged derivative initially through a 4-iminium intermediate; however, in the absence of the $\mathrm{C}(6)$-methyl group, this kinetic product then steadily equilibrates to the thermodynamically favored 4,6-bridged 22 .

Further study confirmed that the conversion of Tc to a 4,11abridged derivatives by $\mathrm{Hg}(\mathrm{OAc})_{2}$ is a general reaction for some tetracyclines. For example, when a solution of tigecycline or minocycline in DMF was treated with 1.1 equivalent of $\mathrm{Hg}(\mathrm{OAc})_{2}$, within an hour, the starting material was quantitatively converted into 4,11a-bridged 4 or 5 ( $>99 \%$ assay yield by HPLC in the form of 7 or 8) and $7 / 8$ was isolated in an impressive 92 and $88 \%$ yield, respectively, after hydrolysis in aqueous EDTA-sodium solution as described above (compare Scheme 1).

In the case of tetracycline, a cleaner and quicker conversion was observed ( $2 \mathrm{~h}, 98 \%$ assay yield and $>90 \%$ isolated yield of the mixture of 11/13/14 with a ratio of 2:1:1 after hydrolysis) (Scheme 2). Doxycycline was found to be less reactive, it took about $6 \mathrm{~h}$ for the reaction to go to completion, and furnished 19 in $76 \%$ isolated yield ( $96 \%$ assay yield by HPLC) (Scheme 3 ). These results demonstrate that $\mathrm{Hg}(\mathrm{OAc})_{2}$ is superior to the $\mathrm{Ag}_{2} \mathrm{CO}_{3} /$ EDTA system to promote this transformation.

Although conversion to 4,1 la-bridged derivatives has been observed for tigecycline, minocycline, doxycycline and tetracycline under the conditions described above, demeclocycline and oxytetracycline failed to undergo this reaction even at elevated temperature. In the case of oxytetracycline, this may be attributed to unfavorable steric interactions of the geminal substituents at $\mathrm{C}(6)$ with the $\mathrm{C}(5)$-hydroxyl in the ring closure conformation; whereas for demeclocycline (Figure 1), we are speculating that the upwards pointing $\mathrm{C}(6)$-hydroxyl substituent may attack the $\mathrm{C}(4)$ iminium ion to form a relatively stable 6membered-ring hemiaminal that effectively blocks the cyclization to the 4,11a-bridged system.

It was also found that neither tigecycline $\mathbf{1}$ nor minocycline $\mathbf{2}$ formed $\mathbf{7}$ or $\mathbf{8}$ through $\mathrm{N}$-chlorosuccinimide ${ }^{12}$ oxidation. These results suggest that the formation of 4,11a-bridged compounds is highly dependent on the structure of the tetracycline and the nature of oxidants.

Finally, we also discovered that under mild heating in acidic aqueous phosphate buffer, $\mathbf{7}$ and $\mathbf{8}$ undergo a novel decarboxylative rearrangement reaction to the more structurally flexible, 'open chain' 1,4-quinoid compounds $\mathbf{2 5 / 2 6}$, potentially through a retro-aldol type mechanism (Scheme 4). To the best of our knowledge, this type of transformation has not been reported before (CAS-SciFinder and Beilstein CrossFire searches, June 11 (2010)).

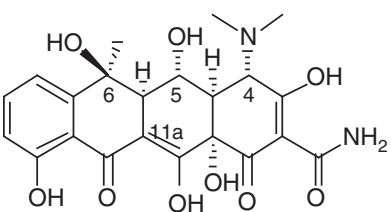

oxytetracycline

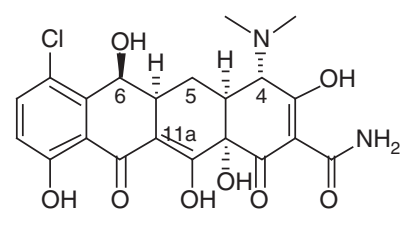

demeclocycline
Figure 1 Demeclocycline and Oxycycline Structures. 
Incidentally, a copper (II) reagent $\left(\mathrm{Cu}(\mathrm{OAc})_{2}\right)$ was found to promote the same conversion from tigecycline and minocycline (but not the other compounds). For tigecycline, the reaction gave a mixture of 7/25 (84:12 by HPLC) after $6 \mathrm{~h}$ at room temperature (DMSO, two equivalents of $\left.\mathrm{Cu}(\mathrm{OAc})_{2}\right)$, and equilibrated to $37: 56$ after $20 \mathrm{~h}$. Minocycline, on the other hand, initially gave a mixture of 8/26 (45:50 by HPLC) after $2 \mathrm{~h}$ at room temperature which slowly equilibrated to a $3: 84$ ratio of $\mathbf{8} / \mathbf{2 6}$ after $20 \mathrm{~h}$. This can be rationalized by the possible formation of ketene 27 directly from $4 / 5$ promoted by the copper reagent (Scheme 4). Curiously, other copper reagents, such as $\mathrm{CuCl}_{2}$ and $\mathrm{CuBr}_{2}$ failed to yield any 4,11a-bridged compounds. Oxidative cations other than $\mathrm{Ag}(\mathrm{I}), \mathrm{Hg}(\mathrm{II})$ and $\mathrm{Cu}(\mathrm{II})$ have not been tested.

In summary, a facile conversion of several members of the tetracycline family to 4,11a-bridged derivatives via an oxidative Mannich cyclization (for a review see Overman ${ }^{13}$ ) promoted by $\mathrm{Ag}_{2} \mathrm{CO}_{3} /$ EDTA or $\mathrm{Hg}(\mathrm{OAc})_{2}$ has been found. The aqueous stability of such bridged compounds and/or 4-iminium cation intermediates is increased by neighboring hydroxyl groups in $\beta$ - or $\delta$-position to the iminium carbon. Furthermore, we also discovered a novel type of rearrangement for some of these bridged compounds that opens the door to open chain quinoid derivatives potentially of interest for the generation of new tetracycline analogs (no scaffolds of this general structure were found in Chemical Abstracts as of August 2010). Antimicrobial activity testing for some of the novel derivatives is pending.

\section{EXPERIMENTAL PROCEDURE}

\section{Synthesis of 4,11a-bridged tigecycline derivative 4}

Method 1 ( $\left.\mathrm{Ag}_{2} \mathrm{CO}_{3} / E D T A\right)$. A mixture of $\mathrm{Ag}_{2} \mathrm{CO}_{3}(552 \mathrm{mg}, 2 \mathrm{mmol})$, EDTA $(350 \mathrm{mg}, 1.2 \mathrm{mmol})$ in anhydrous DMSO $(15 \mathrm{ml})$ was heated at $45^{\circ} \mathrm{C}$ for $1 \mathrm{~h}$, then cooled to room temperature. Tigecycline $(585 \mathrm{mg}, 1 \mathrm{mmol})$ and $4 \AA$ molecular sieves $(500 \mathrm{mg})$ were added and the mixture was stirred at room temperature for $18 \mathrm{~h}$, then filtered through a pad of celite and the pad was washed with acetonitrile. The organic solvents were removed under high vacuum to furnish the product as a dark-green solid; NMR showed traces of EDTA.

Method $2\left(\mathrm{Hg}(\mathrm{OAc})_{2}\right)$. A mixture of tigecycline ( $\left.585 \mathrm{mg}, 1 \mathrm{mmol}\right), \mathrm{Hg}(\mathrm{OAc})_{2}$ ( $383 \mathrm{mg}, 1.2 \mathrm{mmol})$ and $4 \AA$ molecular sieves $(250 \mathrm{mg})$ in anhydrous DMF $(8 \mathrm{ml})$ was stirred at room temperature for $1.5 \mathrm{~h}$. The mixture was filtered through a pad of celite and the pad was washed with acetonitrile. The combined filtrate was concentrated under vacuo to afford $580 \mathrm{mg}$ of the product as an orange solid. Yield: 99\%. HRMS (ESI) calculated for $\mathrm{C}_{29} \mathrm{H}_{38} \mathrm{~N}_{5} \mathrm{O}_{8}\left([\mathrm{M}+\mathrm{H}]^{+}\right)$584.27149, found 584.27153.

Method 3 ( $\left.\mathrm{Hg}(\mathrm{OAc})_{2} / \mathrm{DMSO}-\mathrm{d}_{6}\right)$. A mixture of tigecycline $(146 \mathrm{mg}$, $0.25 \mathrm{mmol}), \mathrm{Hg}(\mathrm{OAc})_{2}(96 \mathrm{mg}, 0.3 \mathrm{mmol})$ and $4 \AA$ molecular sieves $(60 \mathrm{mg})$ in DMSO- $\mathrm{d}_{6}$ anhydrous $(1.5 \mathrm{ml})$ was stirred at room temperature for $1.5 \mathrm{~h}$. The mixture was filtered through a pad of celite. NMR analysis showed that it contained pure product.

\section{Synthesis of 4,11a-bridged minocycline derivative 5}

Method 1 ( $\left.\mathrm{Ag}_{2} \mathrm{CO}_{3} / E D T A\right)$. A mixture of $\mathrm{Ag}_{2} \mathrm{CO}_{3}$ (395 mg, $1.43 \mathrm{mmol}$ ), EDTA $(228 \mathrm{mg}, 0.78 \mathrm{mmol})$ in anhydrous DMF $(10 \mathrm{ml})$ was heated at $50{ }^{\circ} \mathrm{C}$ for $1 \mathrm{~h}$, then cooled to $35^{\circ} \mathrm{C}$. Minocycline $(297 \mathrm{mg}, 0.65 \mathrm{mmol})$ and $4 \AA$ molecular sieves $(500 \mathrm{mg})$ were added and the mixture was stirred at $35^{\circ} \mathrm{C}$ for $40 \mathrm{~h}$, then filtered through a pad of celite. The celite pad was washed with acetonitrile. The organic solvents were removed under high vacuum to furnish the product $(375 \mathrm{mg})$ as a dark-green solid. NMR shows traces of EDTA

Method 2 ( $\left.\mathrm{Hg}(\mathrm{OAc})_{2}\right)$. A mixture of minocycline $(457 \mathrm{mg}, 1 \mathrm{mmol})$, $\mathrm{Hg}(\mathrm{OAc})_{2}(383 \mathrm{mg}, 1.2 \mathrm{mmol})$ and $4 \AA$ molecular sieves $(250 \mathrm{mg})$ in anhydrous DMF $(8 \mathrm{ml})$ was stirred at room temperature for $1 \mathrm{~h}$. The mixture was filtered through a pad of celite and the pad was washed with acetonitrile. The combined filtrate was concentrated under vacuo to afford $446 \mathrm{mg}$ of the product as an orange solid. HRMS (ESI) calculated for $\mathrm{C}_{23} \mathrm{H}_{26} \mathrm{~N}_{3} \mathrm{O}_{7}\left([\mathrm{M}+\mathrm{H}]^{+}\right)$ 456.17653 , found 456.17642

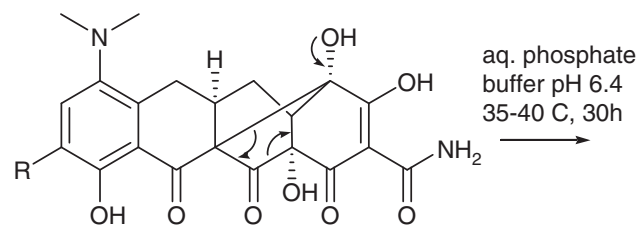

$7 / 8$<smiles>[R]c1cc(N(C)C)c2c(c1O)C(=O)C(=CO)[C@H](CC1=C(O)C(=O)C(C(N)=O)=C(O)C1=O)C2</smiles><smiles>[R]c1cc(N(C)C)c2c(c1O)C(=O)C[C@H](CC1=C(O)C(=O)C(C(N)=O)=C(O)C1=O)C2</smiles>

23<smiles>C1CCOCC1</smiles><smiles>CN(C)c1cc(P)c(O)c2c1C[C@H](CC1=C(O)C(=O)C(C(N)=O)=C(O)C1=O)[C@H](C(=O)O)C2=O</smiles>

24<smiles>[R]c1cc(N(C)C)c2c(c1O)C(=O)C(C=O)=CC2CC1=C(O)C(=O)C(C(N)=O)=C(O)C1=NC</smiles>

Scheme 4 Conversion of 4,11a-bridged 7/8 to p-quinones 25/26. 
Method $3\left(\mathrm{Hg}(\mathrm{OAc})_{2} / \mathrm{DMSO}-d_{6}\right)$. A mixture of minocycline $(114 \mathrm{mg}$, $0.25 \mathrm{mmol}), \mathrm{Hg}(\mathrm{OAc})_{2}(96 \mathrm{mg}, 0.3 \mathrm{mmol})$ and $4 \AA$ molecular sieves $(60 \mathrm{mg})$ in DMSO- $\mathrm{d}_{6}$ anhydrous $(1.5 \mathrm{ml})$ was stirred at room temperature for $1.5 \mathrm{~h}$. The mixture was filtered through a pad of celite and NMR analysis showed pure product.

\section{Synthesis of 4,11a-bridged tigecycline derivative 7}

Method 1 ( $\left.\mathrm{Ag}_{2} \mathrm{CO}_{3} / E D T A\right)$. A mixture of $\mathrm{Ag}_{2} \mathrm{CO}_{3}(552 \mathrm{mg}, 2 \mathrm{mmol})$ and EDTA ( $350 \mathrm{mg}, 1.2 \mathrm{mmol})$ in anhydrous DMSO $(15 \mathrm{ml})$ was heated at $45^{\circ} \mathrm{C}$ for $1 \mathrm{~h}$, then cooled to room temperature. Tigecycline $(585 \mathrm{mg}, 1 \mathrm{mmol})$ and $4 \AA$ molecular sieves $(500 \mathrm{mg}$ ) were added and the mixture was stirred at room temperature for $16 \mathrm{~h}$. The mixture was filtered through a pad of celite and the pad was washed with acetonitrile $(2 \times 15 \mathrm{ml})$. The combined filtrate was then added over $5 \mathrm{~min}$ to an ice-cold saturated EDTA disodium salt solution $(70 \mathrm{ml}$, $\mathrm{pH}$ was adjusted to 5.5 with $\left.5 \mathrm{M} \mathrm{K}_{2} \mathrm{HPO}_{4}\right)$. After addition, the mixture was stirred for an additional $45 \mathrm{~min}$ at $0-5^{\circ} \mathrm{C}$, then filtered through a pad of celite and the filter pad washed with acetonitrile. The filtrate was extracted with chloroform:acetonitrile $(5: 1 \mathrm{v} / \mathrm{v})$ five times. The combined organic layers were dried over sodium sulfate $\left(\mathrm{Na}_{2} \mathrm{SO}_{4}\right)$, filtered and concentrated. The crude was purified by preparative HPLC to give $7(560 \mathrm{mg}$ ) as a yellow powder (as trifluoroacetate salt). Yield: $83 \%$.

Method $2\left(\mathrm{Hg}(\mathrm{OAc})_{2}\right)$. A mixture of tigecycline (585 mg, $\left.1 \mathrm{mmol}\right), \mathrm{Hg}(\mathrm{OAc})_{2}$ $(383 \mathrm{mg}, 1.2 \mathrm{mmol})$ and $4 \AA$ molecular sieves $(250 \mathrm{mg})$ in anhydrous DMF $(8 \mathrm{ml})$ was stirred at room temperature for $1.5 \mathrm{~h}$. The mixture was then added over $5 \mathrm{~min}$ to an ice-cold saturated EDTA disodium salt solution $(35 \mathrm{ml}, \mathrm{pH}$ was adjusted to 5.5 with $5 \mathrm{M} \mathrm{K} \mathrm{HPO}_{4}$ ). After addition, the mixture was stirred for $45 \mathrm{~min}$ at $0-5^{\circ} \mathrm{C}$, then filtered through a pad of celite and the pad was washed with acetonitrile. The combined filtrate was then extracted with chloroform:acetonitrile $(5: 1 \mathrm{v} / \mathrm{v})$ five times. The combined organic layers were dried over sodium sulfate $\left(\mathrm{Na}_{2} \mathrm{SO}_{4}\right)$, filtered and concentrated. The orange residue containing DMF was diluted with $150 \mathrm{ml}$ water, then lyophilized for 2 days. The product was obtained as a yellow powder $(522 \mathrm{mg})$. Yield: 94\%. HRMS (ESI) calculated for $\mathrm{C}_{27} \mathrm{H}_{33} \mathrm{~N}_{4} \mathrm{O}_{9}\left([\mathrm{M}+\mathrm{H}]^{+}\right)$557.22421, found 557.22398

\section{Synthesis of 4,11a-bridged minocycline derivative 8}

Method 1 ( $\mathrm{Ag}_{2} \mathrm{CO}_{3} /$ EDTA). A mixture of $\mathrm{Ag}_{2} \mathrm{CO}_{3}(2.43 \mathrm{~g}, 8.8 \mathrm{mmol})$, EDTA $(1.42 \mathrm{~g}, 4.8 \mathrm{mmol})$ in anhydrous DMF $(60 \mathrm{ml})$ was heated at $50^{\circ} \mathrm{C}$ for $1 \mathrm{~h}$, then cooled to $35^{\circ} \mathrm{C}$. Minocycline $(1.83 \mathrm{~g}, 4 \mathrm{mmol})$ and $4 \AA$ molecular sieves $(2.0 \mathrm{~g})$ were added and the mixture was stirred at $35^{\circ} \mathrm{C}$ for $40 \mathrm{~h}$, then filtered through a pad of celite and the pad was washed with acetonitrile $(40 \mathrm{ml})$. The combined filtrate was then added over $5 \mathrm{~min}$ to an ice-cold saturated EDTA disodium salt solution $\left(260 \mathrm{ml}\right.$, $\mathrm{pH}$ was adjusted to 5.5 with $5 \mathrm{M} \mathrm{K}_{2} \mathrm{HPO}_{4}$ ). After addition, the ice bath was removed and the mixture was stirred at ambient temperature for $45 \mathrm{~min}$, then filtered through another pad of celite and the pad was washed with acetonitrile. The solution was then extracted with chloroform:acetonitrile $(5: 1 \mathrm{v} / \mathrm{v})$ five times. The combined organic layers were dried over sodium sulfate $\left(\mathrm{Na}_{2} \mathrm{SO}_{4}\right)$, filtered and concentrated. The crude was purified by preparative HPLC to give $8(1.10 \mathrm{~g})$ as a light yellow powder. Yield: $64 \%$.

Method $2\left(\mathrm{Hg}(\mathrm{OAc})_{2}\right)$. A mixture of minocycline $(457 \mathrm{mg}, 1 \mathrm{mmol})$, $\mathrm{Hg}(\mathrm{OAc}) 2(383 \mathrm{mg}, 1.2 \mathrm{mmol})$, and $4 \AA$ molecular sieves $(250 \mathrm{mg})$ in anhydrous DMF $(8 \mathrm{ml})$ was stirred at room temperature for $1 \mathrm{~h}$. The mixture was then added over $5 \mathrm{~min}$ to an ice-cold saturated EDTA disodium salt solution $(30 \mathrm{ml}$, $\mathrm{pH}$ was adjusted to 5.5 with $5 \mathrm{~m} \mathrm{~K} 2 \mathrm{HPO} 4) / 8 \mathrm{ml} \mathrm{MeCN}$. After addition, the mixture was stirred for $30 \mathrm{~min}$ at $0-5^{\circ} \mathrm{C}$, then filtered through a pad of celite and the pad was washed with acetonitrile. The combined filtrate was then extracted with chloroformacetonitrile $(5: 1 \mathrm{v} / \mathrm{v})$ five times. The combined organic layers were dried over sodium sulfate ( $\mathrm{Na} 2 \mathrm{SO} 4)$, filtered and concentrated. The residue containing DMF was diluted with $150 \mathrm{ml}$ water and lyophilized for 2 days. The product was obtained as a light yellow powder (376 mg). Yield: $87.5 \%$. HRMS (ESI) calculated for C21H21N2O8 $([\mathrm{M}+\mathrm{H}]+)$ 429.12924, found 429.12914

\section{Synthesis of 4,11a-bridged tetracycline derivative 11}

Method $1\left(\mathrm{Ag}_{2} \mathrm{CO}_{3} / E D T A\right)$. A mixture of $\mathrm{Ag}_{2} \mathrm{CO}_{3}(1.82 \mathrm{~g}, 6.6 \mathrm{mmol})$, EDTA $(1.05 \mathrm{~g}, 3.6 \mathrm{mmol})$ in anhydrous DMF $(45 \mathrm{ml})$ was heated at $50^{\circ} \mathrm{C}$ for $1 \mathrm{~h}$, then cooled to $37^{\circ} \mathrm{C}$. Tetracycline $(1.33 \mathrm{~g}, 3 \mathrm{mmol})$ and $4 \AA$ molecular sieves $(2.0 \mathrm{~g})$ were added and the mixture was stirred at $37^{\circ} \mathrm{C}$ for $48 \mathrm{~h}$, then filtered through a pad of celite and the pad was washed with acetonitrile. The organic solvents were removed under high vacuum to furnish the product as an orange-red solid. NMR shows traces of EDTA.

Method $2\left(\mathrm{Hg}(\mathrm{OAc})_{2}\right)$. A mixture of tetracycline (444 mg, $\left.1 \mathrm{mmol}\right), \mathrm{Hg}(\mathrm{Oac})_{2}$ $(383 \mathrm{mg}, 1.2 \mathrm{mmol})$ and $4 \AA$ molecular sieves $(250 \mathrm{mg})$ in anhydrous DMF $(8 \mathrm{ml})$ was stirred at room temperature for $2 \mathrm{~h}$. The mixture was filtered through a pad of celite and the pad was washed with acetonitrile. The combined filtrate is concentrated under vacuo to afford $460 \mathrm{mg}$ of the product as a light brown solid. HRMS (ESI) calculated for C22H23N2O8 $([\mathrm{M}+\mathrm{H}]+)$ 443.14489 , found 443.14464

\section{Synthesis of 4,6-bridged tetracycline derivative 14}

Method 1 ( $\left.\mathrm{Ag}_{2} \mathrm{CO}_{3} / E D T A\right)$. A mixture of $\mathrm{Ag}_{2} \mathrm{CO}_{3}(1.82 \mathrm{~g}, 6.6 \mathrm{mmol})$ and EDTA $(1.05 \mathrm{~g}, 3.6 \mathrm{mmol})$ in anhydrous DMF $(45 \mathrm{ml})$ was heated at $50{ }^{\circ} \mathrm{C}$ for $1 \mathrm{~h}$, then cooled to $37^{\circ} \mathrm{C}$. Tetracycline $(1.33 \mathrm{~g}, 3 \mathrm{mmol})$ and $4 \AA$ molecular sieves $(2.0 \mathrm{~g})$ were added and the mixture was stirred at $37^{\circ} \mathrm{C}$ for $48 \mathrm{~h}$, The mixture was filtered through a pad of celite and the pad was washed with acetonitrile $(50 \mathrm{ml})$. The combined filtrate was then added over $5 \mathrm{~min}$ to an ice-cold saturated EDTA disodium salt solution $(200 \mathrm{ml}, \mathrm{pH}$ was adjusted to 5.5 with $5 \mathrm{M} \mathrm{K} \mathrm{HPO}_{4}$ ). After addition, the mixture was stirred at $0-5^{\circ} \mathrm{C}$ for $8 \mathrm{~h}$, HPLC indicated the ratio of $\mathbf{1 1 / 1 3 / 1 4}$ was about $1 / 5 / 3$. The mixture was filtered through pad of celite and the pad was washed with acetonitrile $(100 \mathrm{ml})$. The filtrate was extracted with chloroform $(3 \times 150 \mathrm{ml})$. The combined organic layers were dried over sodium sulfate, filtered and concentrated to about $40 \mathrm{ml}$ volume. The solution was then kept at $0-5{ }^{\circ} \mathrm{C}$ for 7 days, during this period, the ratio of 13/14 changed from about 5:3 to 1:5. The crude material was purified by preparative HPLC to give $\mathbf{1 4}(520 \mathrm{mg})$ as a light brown powder. Yield: $42 \%$. HRMS (ESI) calculated for $\mathrm{C}_{20} \mathrm{H}_{18} \mathrm{NO}_{9}\left([\mathrm{M}+\mathrm{H}]^{+}\right)$416.09760, found 416.09746

Method $2\left(\mathrm{Hg}(\mathrm{OAc})_{2}\right)$. A mixture of tetracycline (444 mg, $\left.1 \mathrm{mmol}\right), \mathrm{Hg}(\mathrm{OAc})_{2}$ $(383 \mathrm{mg}, 1.2 \mathrm{mmol})$ and $4 \AA$ molecular sieves $(250 \mathrm{mg})$ in anhydrous DMF $(8 \mathrm{ml})$ was stirred at room temperature for $2 \mathrm{~h}$. The mixture was then added over $5 \mathrm{~min}$ to an ice-cold saturated EDTA disodium salt solution $(35 \mathrm{ml}, \mathrm{pH}$ was adjusted to 5.5 with $\left.5 \mathrm{M} \mathrm{K} \mathrm{K}_{2} \mathrm{HPO}_{4}\right) / 12 \mathrm{ml} \mathrm{MeCN}$. After addition, the mixture was stirred at $0-5^{\circ} \mathrm{C}$ for $1 \mathrm{~h}$, HPLC indicated the ratio of $11 / 13 / 14$ was about 43/36/20. The mixture was filtered through a pad of celite and the pad was washed with acetonitrile. The combined filtrate was then extracted with chloroform $(4 \times 100 \mathrm{ml})$. The organic layers were dried over sodium sulfate $\left(\mathrm{Na}_{2} \mathrm{SO}_{4}\right)$, filtered and concentrated. The residue was diluted with $200 \mathrm{ml}$ of water and lyophilized for 2 days. The product was obtained as a light yellow powder $(398 \mathrm{mg})$ as a mixture of $\mathbf{1 1 / 1 3 / 1 4}$ with the ratio of 44/28/26.

\section{Synthesis of 4,11a-bridged doxycycline derivative 19}

Method $1\left(\mathrm{Ag}_{2} \mathrm{CO}_{3} / E D T A\right)$. A mixture of $\mathrm{Ag}_{2} \mathrm{CO}_{3}(1.44 \mathrm{~g}, 5.2 \mathrm{mmol})$ and EDTA $(701 \mathrm{mg}, 2.4 \mathrm{mmol})$ in anhydrous DMF $(30 \mathrm{ml})$ was heated at $50^{\circ} \mathrm{C}$ for $1 \mathrm{~h}$, then cooled to $37^{\circ} \mathrm{C}$. Doxycycline $(888 \mathrm{mg}, 2 \mathrm{mmol})$ and $4 \AA$ molecular sieves $(1.4 \mathrm{~g})$ were added and the mixture was stirred at $37^{\circ} \mathrm{C}$ for $40 \mathrm{~h}$, then filtered through a pad of celite and the pad was washed with acetonitrile $(30 \mathrm{ml})$. The combined filtrate was then added to an ice-cold saturated EDTA disodium salt solution $\left(100 \mathrm{ml}\right.$, pH was adjusted to 5.5 with $5 \mathrm{M} \mathrm{K}_{2} \mathrm{HPO}_{4}$ ). After addition, the cooling bath was removed and the mixture was stirred at ambient temperature for $30 \mathrm{~min}$. The mixture was filtered through a pad of celite and the filter pad was rinsed with acetonitrile $(100 \mathrm{ml})$. The filtrate was extracted with chloroform:acetonitrile $(5: 1 \mathrm{v} / \mathrm{v})(3 \times 150 \mathrm{ml})$. The combined organic layers were dried over sodium sulfate $\left(\mathrm{Na}_{2} \mathrm{SO}_{4}\right)$, filtered and concentrated to about $15 \mathrm{ml}$ volume. This concentrate was then added over $5 \mathrm{~min}$ to ice-cold water $(60 \mathrm{ml})$. After stirring for $15 \mathrm{~min}$, the precipitated solid was collected on a Buchner funnel and washed with cold water. Drying at high vac. overnight furnished $19(710 \mathrm{mg})$ as a light gray powder (HPLC $>98 \mathrm{~A} \%$ ). 
Method $2\left(\mathrm{Hg}(\mathrm{OAc})_{2}\right)$. A mixture of doxycycline (444 mg, $\left.1 \mathrm{mmol}\right), \mathrm{Hg}(\mathrm{OAc})_{2}$ $(383 \mathrm{mg}, 1.2 \mathrm{mmol})$ and $4 \AA$ molecular sieves $(250 \mathrm{mg})$ in anhydrous DMF $(8 \mathrm{ml})$ was stirred at room temperature for $6 \mathrm{~h}$. The mixture was added to an ice-cold saturated EDTA disodium salt solution $(30 \mathrm{ml}, \mathrm{pH}$ was adjusted to 5.5 with $5 \mathrm{M}$ $\left.\mathrm{K}_{2} \mathrm{HPO}_{4}\right) / 12 \mathrm{ml} \mathrm{MeCN}$. After addition, the cooling bath was removed and the mixture was stirred at ambient temperature for $30 \mathrm{~min}$. The mixture was filtered through a pad of celite and the filter pad was rinsed with acetonitrile. The filtrate was extracted with chloroform:acetonitrile $(5: 1 \mathrm{v} / \mathrm{v})(3 \times 100 \mathrm{ml})$. The combined organic layers were dried over sodium sulfate, filtered and concentrated. The residue was then added over $5 \mathrm{~min}$ to ice-cold water $(35 \mathrm{ml})$, after stirring for $15 \mathrm{~min}$, the precipitates were collected on a Buchner funnel and washed with cold water, the wet cake was then dried at high vac. overnight to give $\mathbf{1 9}(286 \mathrm{mg})$ as a light gray powder (HPLC $>99 \mathrm{~A} \%$ ). HRMS (ESI) calculated for $\mathrm{C}_{22} \mathrm{H}_{23} \mathrm{~N}_{2} \mathrm{O}_{8}$ $\left([\mathrm{M}+\mathrm{H}]^{+}\right)$443.14489, found 443.14481 .

\section{Synthesis of tigecycline derivative 25}

Compound $7(100 \mathrm{mg}, 0.18 \mathrm{mmol})$ was dissolved in $25 \mathrm{~mm}$ potassium phosphate buffer ( $4 \mathrm{ml}$, pH6.4) containing $2.5 \mathrm{~mm}$ EDTA disodium and the mixture was stirred at $35^{\circ} \mathrm{C}$ for $30 \mathrm{~h}$. Preparative HPLC furnished compound 25 $(40 \mathrm{mg})$ as a dark-red powder. Yield: $42 \%$. HRMS (ESI) calculated for $\mathrm{C}_{26} \mathrm{H}_{33} \mathrm{~N}_{4} \mathrm{O}_{8}\left([\mathrm{M}+\mathrm{H}]^{+}\right)$529.22929, found 529.22905.

\section{Synthesis of minocycline derivative 26}

A solution of compound $8(180 \mathrm{mg}, 0.42 \mathrm{mmol})$ in $25 \mathrm{~mm}$ potassium phosphate buffer $(3 \mathrm{ml}, \mathrm{pH} 6.4)$ containing $2.5 \mathrm{~mm}$ EDTA disodium and $\mathrm{MeCN}$ $(3 \mathrm{ml})$ was stirred at $35^{\circ} \mathrm{C}$ for $24 \mathrm{~h}$. Preparative HPLC furnished compound 26 (93 mg) as a reddish brown powder. Yield: 55\%. HRMS (ESI) calculated for $\mathrm{C}_{20} \mathrm{H}_{21} \mathrm{~N}_{2} \mathrm{O}_{7}\left([\mathrm{M}+\mathrm{H}]^{+}\right)$401.13433, found 401.13411.

\section{Supplementary Information}

Characterization of compounds $4,5,7,8,11,14,19,25$ and 26 . NMR $\left({ }^{1} \mathrm{H},{ }^{13} \mathrm{C}\right.$, 2D (HMBC, HSQC)) spectra for compounds 4, 5, 7, 8, 11, 14, 19 and 26. HPLC spectra for compounds 7, 8 and 19 and the mixture of 11, 13 and 14. Analytical and preparative HPLC method information.

\section{ACKNOWLEDGEMENTS}

We thank Dr Xidong Feng for FT-MS analyses and Dr Jeffrey Sperry for proofreading this manuscript.

1 Sum, P-. E. Case studies in current drug development: 'glycylcyclines'. Curr. Opin. Chem. Biol. 10, 374-379 (2006).

2 Rose, W. E. \& Rybak, M. J. Tigecycline: first of a new class of antimicrobial agents. Pharmacotherapy 26, 1099-1110 (2006).

3 Sum, P-. E. \& Petersen, P. Synthesis and structure-activity relationship of novel glycylcycline derivatives leading to the discovery of GAR-936. Bioorg. Med. Chem. Lett 9, 1459-1462 (1999).

4 Sum, P-. E., How, D. B., Hopper, D. W., Vera, M. D. \& Sabatini, J. J. (Wyeth) Preparation of oxazole derivatives of tetracyclines as antibacterial agents WO 2005056538, Jun 23 (2005).

5 Drexel, R. E. et al. Organic photochemistry. 82. Lumitetracycline. A new tetracycline photoproduct. J. Org. Chem. 55, 2471-2478 (1990).

6 Olack, G. \& Morrison, H. Organic photochemistry. 92. Formation and characterization of lumitetracycline-type photoproducts from members of the tetracycline family. J. Org. Chem. 56, 4969-4971 (1991).

7 Jogun, K. H. \& Stezowski, J. J. Chemical-structural properties of tetracycline derivatives. 2. Coordination and conformational aspects of oxytetracycline metal ion complexation. J. Am. Chem. Soc. 98, 6018-6026 (1976).

8 Orth, P., Saenger, W. \& Hinrichs, W. Tetracycline-chelated $\mathrm{Mg}^{2+}$ ion initiates helix unwinding in tet repressor induction. Biochemistry 38, 191-198 (1999).

9 Nowack, B. Environmental chemistry of aminopolycarboxylate chelating agents. Environ. Sci. Technol. 36, 4009-4016 (2002).

$10 \mathrm{Gu}, \mathrm{C} . \&$ Karthikeyan, K. G. Interaction of tetracycline with aluminum and iron hydrous oxides. Environ. Sci. Technol. 39, 2660-2667 (2005).

11 Esse, R. C., Lowery, J. A., Tamorria, C. R. \& Sieger, G. M. Tetracycloxides. I. A new class of tetracycline derivatives. J. Am. Chem. Soc. 86, 3874-3875 (1964).

12 Barton, D. H. R., Ley, S. V., Meguro, K. \& Williams, D. J. Reaction of tetracycline hydrochloride with $\mathrm{N}$-chlorosuccinimide: x-ray structure of the major product. J. Chem. Soc. Chem. Commun. 86, 790-791 (1977).

13 Overman, L. E. Charge as a key component in reaction design. The invention of cationic cyclization reactions of importance in synthesis. Acc. Chem. Res. 25, 352-359 (1992).

Supplementary Information accompanies the paper on The Journal of Antibiotics website (http://www.nature.com/ja) 